WIDER Working Paper 2017/35

\title{
An evaluation of interest deduction limitations to counter base erosion in South Africa
}

Pieter Van der Zwan, ${ }^{1}$ Danie Schutte, ${ }^{1}$ Waldo Krugell, ${ }^{1}$ Joel Seshabela, ${ }^{1}$ Hayley Reynolds, ${ }^{2}$ and Londiwe Khoza ${ }^{2}$

February 2017 
Abstract: This paper aims to describe funding structures of companies liable for tax in South Africa and how this relates to other characteristics, including ownership, of the companies. The research that the paper reports on was performed as descriptive analyses. While no clear indication of a preference for debt could be identified, the results showed that the mean net interest coverage ratio for certain foreign-owned entities differed significantly from that of domestically owned entities. This may be evidence of profit-shifting activities. The results highlight trends in interest coverages ratios that may be of relevance for future legislative developments.

Keywords: interest deduction limitation, interest coverage ratio, profit shifting, South Africa JEL classification: H20, H25, H26

\footnotetext{
${ }^{1}$ North-West University; Potchefstroom, South Africa; corresponding author: Pieter.VanDerZwan@nwu.ac.za, ${ }^{2}$ National Treasury, Pretoria, South Africa.

This study has been prepared within the UNU-WIDER project on 'Regional growth and development in Southern Africa'.

Copyright (C) UNU-WIDER 2017

Information and requests: publications@wider.unu.edu

ISSN 1798-7237 978-92-9256-259-5

Typescript prepared by Merl Storr.
}

The United Nations University World Institute for Development Economics Research provides economic analysis and policy advice with the aim of promoting sustainable and equitable development. The Institute began operations in 1985 in Helsinki, Finland, as the first research and training centre of the United Nations University. Today it is a unique blend of think tank, research institute, and UN agency_providing a range of services from policy advice to governments as well as freely available original research.

UNU-WIDER acknowledges specific programme contribution from the National Treasury of South Africa to its project 'Regional growth and development in Southern Africa' and core financial support to its work programme from the governments of Denmark, Finland, Sweden, and the United Kingdom.

Katajanokanlaituri 6 B, 00160 Helsinki, Finland

The views expressed in this paper are those of the author(s), and do not necessarily reflect the views of the Institute or the United Nations University, nor the programme/project donors. 
As part of the Organization for Economic Cooperation and Development (OECD)/Group of Twenty (G20) ${ }^{1}$ project on base erosion and profit shifting (BEPS), the OECD identified the deductibility of interest for purposes of calculating taxable profits as one of the areas that required attention (to counter BEPS) (OECD 2013). This led to an analysis under Action 4, 'Limiting Base Erosion Involving Interest Deductions and Other Financial Payments', of the OECD/G20 BEPS Project.

The final Action 4 Report, issued during 2015, notes that 'The use of third party and related party interest is perhaps one of the most simple of the profit-shifting techniques available in international tax planning. The fluidity and fungibility of money makes it a relatively simple exercise to adjust the mix of debt and equity in a controlled entity' (OECD 2015: 15). It contains recommendations (best practice) for governments to implement proposed measures to address the risks posed to the corporate tax base by interest payments and the related tax deductions. The suggested approach includes a general interest limitation (core rule) based on an interest-to-profit ratio. This is coupled with de minimis exclusion rules, exceptions for highly geared groups, and specific anti-avoidance rules to target identified instances not addressed by the general interest limitation rule (OECD 2015).

The South African Income Tax Act (Act 58 of 1962) (Act) ${ }^{2}$ contains certain measures aimed at countering the risk of base erosion through interest deductions. Since its introduction, Section 31 of the Act has contained anti-avoidance provisions in the form of transfer pricing adjustments for interest incurred at excessive rates or interest paid on excessive amounts of debt (thin capitalization) by taxpayers in relation to foreign funding by connected persons. During 2014 and 2015, focused anti-avoidance rules that limit the deduction of interest incurred in respect of debt used to fund certain reorganization transactions (Section $23 \mathrm{~N}$ ), as well as interest paid to connected persons where such interest is not taxed in South Africa in the hands of such recipients (Section $23 \mathrm{M}$ ), were introduced into the Act. Both of these provisions apply an interest limit based on the ratio between the particular interest and a tax proxy for interest-adjusted earnings before interest, taxes, depreciation, and amortization (EBITDA) (National Treasury 2014b). The deductible interest ratio applied in these provisions is based on a formula that varies according to changes in the repurchase rate set by the South African Reserve Bank, and has a ceiling rate of 60 per cent of the interest-adjusted EBITDA proxy (National Treasury 2014b). In addition, a withholding tax on interest paid to foreign persons was introduced with effect from 1 March 2015, as a method of countering base erosion (National Treasury 2013).

Even though South Africa is not a member of the OECD, it participated actively in the OECD/G20 BEPS project. The recommendations stemming from Action 4 should therefore be considered by the National Treasury and the South African Revenue Service (SARS). In this regard, a number of key differences exist between the current South African measures to address the risk of base erosion from interest deductions, as discussed above, and the best practice approach suggested by the OECD. These include that the South African reliance on the arm's length approach to provide an overall protection mechanism is relatively high, while the OECD questions the effectiveness of this approach (OECD 2015). In addition, the South African measures

\footnotetext{
${ }^{1}$ In September 2013 the G20 Leaders endorsed the Base Erosion and Profit Shifting (BEPS) Action Plans to be carried out by the OECD.

${ }^{2}$ Any reference to a section in this document refers to a section of the Act unless indicated otherwise.
} 
implemented focus on interest paid in respect of related party debt, while the OECD's proposal suggests an overall interest deduction limitation that would apply to both multinationals and standalone domestic entities (OECD 2015) but notes that countries should decide what is best for their economies. The range of acceptable levels of interest in relation to profits suggested by the OECD (10 to 30 per cent) appears to be significantly lower than those contained in specific South African anti-avoidance provisions. From this brief analysis, it is evident that the implementation or partial implementation of the OECD's recommendations from Action 4 is likely to result in stricter interest deduction limitations in South Africa. In the 2016 Budget Review, the National Treasury highlighted heavily geared financing structures that lead to excessive interest deductions and erosion of the corporate tax base as being of concern. If further measures are introduced to limit the tax deductibility of interest more closely aligned with the OECD's recommendations, this may confirm the above view regarding stricter limitations (National Treasury 2016).

However, the limitation of interest deductions and related anti-avoidance rules can have a direct impact on returns earned by investors (Haufler and Runkel 2012). If this is the case, it might influence the attractiveness of South Africa as an investment destination. The need to increase investment and attract foreign direct investment is clear, and has been recognized by government (Department: Trade and Industry 2016; South African Government 2016). Such investment is a source of foreign currency, and multinational corporations can provide technological spillovers and skills transfers that increase productivity and drive economic growth.

\section{$2 \quad$ Research focus}

A fine balance needs to be struck between protecting the tax base by considering the recommendations flowing from Action 4 of the OECD/G20 BEPS Project and creating an attractive environment that will encourage investment activity to contribute to the growth of the South African economy. To strike this balance, a thorough understanding of the relationship between funding structures of companies operating in South Africa and the characteristics of such companies must be gained. To our knowledge, no published studies using firm-level data have been performed in the South African context to date.

To address this gap, the research reported in this working paper aimed to answer the following primary research question:

What describes the funding structures of different types of entities, in particular foreign-owned entities and domestically owned entities, and how is it related to other characteristics of the firms?

The secondary question considered in this research project was:

Depending on the results of the primary research question, is there a relationship between funding structure and economic activities (such as production, productivity, or employment) influenced by the funding structure of the entity?

The above questions were primarily considered through descriptive analysis of data contained in the CIT-IRP5 Panel Data, as described by Flowerday et al. (2016). This panel contains an observation for each year of assessment for each company that submitted a tax return for that 
period. ${ }^{3}$ During this period, two versions of the company tax return were used, namely the IT14 (prior to May 2013) and the ITR14 (from May 2013). Table 1 describes the number of observations contained in the panel.

Table 1: Description of population contained in panel

\begin{tabular}{lc}
\hline & $\begin{array}{c}\text { Number of } \\
\text { observations }\end{array}$ \\
\hline 2008 & 882643 \\
2009 & 935977 \\
2010 & 941736 \\
2011 & 925740 \\
2012 & 898784 \\
2013 & 874340 \\
2014 & 781839 \\
2015 & 245072 \\
2016 & 13430 \\
Total & $\mathbf{6 4 9 9 5 6 1}$ \\
\hline
\end{tabular}

Source: authors' compilation from the panel data.

Other than the generation of new variables from the existing data in the panel to calculate certain financial ratios, as described in the remainder of this paper, no modifications were made to the panel data for the purposes of the research.

To compare the positions of foreign-owned and domestic-owned companies, the data is described for three categories of taxpayers identifiable in the panel, namely entities indicated as being foreignowned, ${ }^{4}$ foreign branches, ${ }^{5}$ and all entities that do not fall within these two categories (assumed to be domestically owned). This distinction can only be drawn using information obtained from the ITR14, which came into use from May 2013, as the information was not previously requested from taxpayers in the IT14 return. The research was therefore only performed in respect of companies that filed ITR14 returns. This inherently limits the results to returns submitted from May 2013 to 2016. Since there was only a limited number of returns included for the 2016 year when the panel data was compiled, the information pertaining to 2016 was also omitted. As a result, the returns primarily relate to years of assessment ending during 2013 to 2015. The findings described in section 6 below only relate to this portion of the population. The numbers of observations for tax returns submitted by the respective categories of entities are presented in Table 2.

\footnotetext{
${ }^{3}$ Each observation represents a tax return submitted by a taxpayer for a particular year of assessment. In principle, a specific taxpayer should have an observation for each year if that taxpayer submitted an income tax return for all years that it was obligated to do so.

${ }^{4}$ The field in the ITR14 requires a taxpayer to indicate whether it is a controlled group company in relation to a foreign company. A foreign entity would be the controlling group company in relation to a South African company if that foreign entity, together with controlled group companies, held at least 70 per cent of the equity shares and voting rights of the South African entity (see the definition of 'group of companies' in Section 1 of the Act). The South African-controlled group company is taxed as a person separate from its controlling group company.

${ }^{5}$ The field in the ITR14 requires a taxpayer to indicate whether the return was submitted in respect of a branch, permanent establishment, or agency of a foreign company. The branch is not a separate taxpayer from the company of which it forms a part. The foreign company is liable for tax in South Africa on the taxable income earned from a South African source. In instances where the branch represents a permanent establishment, an allocation of profits towards the permanent establishment is required.
} 
Table 2: Classification of observations submitted using ITR14 return

\begin{tabular}{|c|c|c|c|c|}
\hline & 2013 & 2014 & 2015 & Total \\
\hline $\begin{array}{l}\text { Entities that have a foreign controlling group } \\
\text { company (hereafter described as 'foreign-held } \\
\text { companies') }\end{array}$ & 2759 & 2887 & 452 & 6098 \\
\hline $\begin{array}{l}\text { Entities that are branches of foreign companies } \\
\text { (hereafter described as 'South African branches } \\
\text { of foreign companies') }\end{array}$ & 16070 & 11941 & 549 & 28560 \\
\hline $\begin{array}{l}\text { Remaining companies (hereafter described as } \\
\text { 'entities other than foreign-held companies or } \\
\text { South African branches' or domestically owned) }\end{array}$ & 855511 & 767011 & 244071 & 1866593 \\
\hline Total observations & 874340 & 781839 & 245072 & 1901251 \\
\hline
\end{tabular}

Source: authors' compilation from the panel data.

The theoretical underpinnings, as well as the variables generated and reports drawn based on these underpinnings, are discussed in section 3 of this paper.

\section{Literature that underpins the analysis performed in relation to funding structure and cost of funding}

Firms' operations are generally financed from two main sources, namely debt and equity. Equity can be further divided into internal funds and new equity. A hierarchy of financing sources exists, according to pecking order theory (Myers and Majluf 1984). In terms of this theory, where external funding is required managers will tend to prefer debt over equity, so as to avoid 'external ownership' in the company among other reasons. There is also a possibility that the choice between debt and equity funding may be impacted by the costs and benefits of using debt to finance operations.

The advantages of debt include increased tax shields, whilst the downside may be that high debt levels increase the risk of financial distress. From a tax perspective, debt financing is preferred because interest payments reduce the taxable income of a company while dividends and share repurchases do not (Langedijk et al. 2014). This tax benefit of debt financing often encourages excessive debt financing, which results in complex financial transactions and high leveraged ownership, which would not normally exist if the pecking order theory were applied (Hemmelgarn and Nicodème 2010; Lloyd 2012; Shackleford et al. 2010; Shaviro 2009).

Besides the general debt bias from which both purely domestic and multinational entities can benefit, the preference for debt funding often increases in circumstances where the funding is advanced directly or indirectly by an entity affiliated to the borrowing company. For example, the owner or shareholder may be indifferent as to the choice of instrument, given that this does not necessarily impact on its risk exposure (Buettner et al. 2012; Gajewksi 2013). This often results in minimal equity funding and high levels of internal debt, known as thin capitalization, to enjoy the benefits of the tax deductibility of the interest on debt (Buettner et al. 2016; Gopalan et al. 2007). The cross-border context means that multinationals can strategically place (shift) debt in high-tax jurisdictions so as to reduce taxable profits that are subject to relatively high effective tax rates in comparison with affiliates in other jurisdictions (OECD 2015).

Over the years, many jurisdictions have implemented thin capitalization rules that effectively limit the deduction of interest in respect of affiliated entity debt (Buettner et al. 2012; Buettner et al. 2016; Wamser 2014). However, these rules may result in an entity making use of external debt funding from an independent person. Doing so would still yield a deduction for the interest—with 
the associated tax benefit- to which the thin capitalization rules would generally not apply (Buettner et al. 2012; Wamser 2014).

The OECD (2015) notes that methods to counter base erosion through interest deductions include transfer pricing mechanisms, such as arm's length tests, and withholding taxes. Thin capitalization mechanisms generally involve the use of explicit threshold levels for the debt-to-equity ratio (Buettner et al. 2016). Erosion of the tax base through interest deductions may also be prevented by provisions allowing specified percentages of interest or limitations on the amount of interest deductible with reference to certain ratios (OECD 2015). Such measures have been implemented by a number of European countries since 2008, including Germany, the Netherlands, the United Kingdom, and Italy. These measures are often not limited to interest in relation to debts from affiliated persons only, but also apply to interest on external debt (Giacometti and Meloni 2008; Knauer and Sommer 2012; Marino and Russo 2008; Saparoea 2009). In addition, the OECD (2015) states that countries may consider introducing rules targeted at interest arising from specific transactions. Each of the above methods or bases for limiting interest deductions has certain advantages but also weaknesses.

For purposes of corporate finance and management, the debt-to-equity ratio is an indication of the solvency and level of financial gearing of an entity (Els et al. 2010: 70). To optimize shareholder value, an optimal mix between debt and equity is required (Els et al. 2010: 76). As such it is submitted that a debt-equity ratio provides valuable information about the capitalization of an entity from a commercial perspective. Traditionally many jurisdictions have used a balance sheet approach (normally a ratio between debt and equity) as an indicator of whether an entity is thinly capitalized or not (Webber 2010b: 687). This approach provides taxpayers and tax authorities with a method that is relatively simple to apply (OECD 2015: 21; Webber 2010b: 685).

However, the balance sheet approach has been criticized, as it does not take into account the productivity of a firm (Mardan 2013: 2). This shortcoming of a fixed balance sheet ratio can be addressed by using an earning-stripping approach to limit interest deductions. Prescribing a limit by reference to EBITDA, as opposed to the relative amount of debt to equity, has the advantage that it is linked directly to the tax base that needs to be protected (Barnes 2014). In contrast, if a balance sheet approached is followed, the absolute acceptable level of debt, and therefore interest deductions, can be increased by increasing the equity amount (von Brocke and Perez 2009: 29; Webber 2010a: 19).

Miesel et al. (2003: 2) posit that multinational entities might enter into transactions that independent parties would not normally enter into-for example, funding entities that are lossmaking or less profitable but that have some strategic importance-and thus make it difficult to achieve comparability analysis as suggested by OECD guidelines. Yao (2013) agrees with Miesel et al. in that the arm's length approach is aimed at increasing tax revenues in a perfect market. Even though this would make the return on investment low or unproductive, it might hold certain tax benefits for an investor. Therefore the tax base can still be eroded even though the debt-to-equity ratio appears acceptable. Multinational entities may be willing to enter into such funding arrangements for this purpose. Given this, different entities of the same group may be allowed different levels of interest deductions depending on their location and the tax rates applicable, even if profit levels are similar, which could lead to base erosion (Barnes 2014).

The OECD (2015: 22) acknowledged the possible increase in administration and compliance costs as a drawback of complex targeted rules, which are likely to stem from the recommendations in Action 4 that may require ratios to be determined at entity level, at group level, and by specific targeted rules. 


\section{$4 \quad$ Methodology and approach}

Following on from the discussion above, and due to the potential design flaws of interest limitation rules and other rules to counter thin capitalization and excessive interest deductions, the descriptive analysis considers both debt-to-equity and interest coverage ratios. The aim is to provide a picture of the capitalization trends for the three categories of entities.

\subsection{Indicators of the level of gearing}

Countries that use the concepts of debt and equity need to define those terms (Barnes 2014; Khumalo 2015: 4). Some examples of the differences that can exist relate to whether total debt is used, whether deferred tax is included as debt or not, and how shareholder-backed bank loans are treated (Buettner et al. 2012). For the purposes of this research, the meanings of the terms were based on the McGregor/Inet $\mathrm{BFA}^{6}$ classification. In that context, debt is computed by adding convertible debentures, directors' and shareholders' loans, long-term non-interest-bearing loans, long-term interest-bearing loans, and current liabilities. ${ }^{7}$ McGregor BFA calculates equity as the sum of ordinary share capital, share premium, non-distributable reserves, and distributable reserves. Since the CIT-IRP5 Panel Data does not contain total equity or total liability fields, these totals were generated for the purposes of the descriptive analysis, together with a debt-to-equity ratio based on these totals.

\subsection{Indicators of the level of funding costs}

\section{Basis for determination of the limitation}

The OECD (2015) indicates that a best practice approach is based around a fixed ratio rule that limits an entity's net interest deductions to a fixed percentage of its profit, measured using EBITDA. It is recommended that tax amounts be used to determine EBITDA. This is also the approach followed in Sections $23 \mathrm{M}$ and $23 \mathrm{~N}$ of the Act, which use the concept of adjusted taxable income as a basis for the interest limitation.

At the time of introduction of Section 23M, the National Treasury provided statistics on interestto-EBIT and interest-to-EBITDA ratios using data from Statistics South Africa for a sample of companies (National Treasury 2014a). The statistics indicated interest-to-EBITDA ratios ranging between 10 and 15 per cent. It is submitted that these EBITDA bases were not determined using tax amounts. The CIT-IRP5 Panel Data did not contain an EBITDA field or ratios based on EBITDA. In addition, the CIT-IRP5 Panel Data did not contain disaggregated adjustments necessary to accurately determine the EBITDA ratio using tax data. Hence EBITDA ratios were generated for the purposes of the descriptive analysis based on firms' accounting profits adjusted for interest and depreciation.

\footnotetext{
${ }^{6} \mathrm{McGregor} /$ Inet BFA is a provider of financial data feeds and analysis tools.

${ }^{7}$ It is submitted that current liabilities would generally not pose a threat to the tax base through erosion by interest payments in respect of such liabilities.
} 
The OECD (2015) considered applying the limitation to both gross and net interest incurred. In this regard, arguments include, for example, that net interest is susceptible to potential manipulation, while the use of gross interest may lead to double taxation that may arise in the case of back-to-back loans. Furthermore, using the gross basis would render the limitations simpler to apply. To establish the effect of applying the limitation on a net or gross basis, the descriptive analysis includes a comparison between levels of net interest and gross interest incurred, as well as a number of ratios determined using the respective interest amounts.

\section{Amount subject to the limitation}

As indicated above, both interest incurred in respect of debt owing to affiliated entities and external debt may pose a risk of base erosion. The data available in the panel only allowed an analysis of total debt (in relation to capital structure ratios) and total interest (in relation to the interest coverage ratios). Ideally, separate analyses should be performed in respect of the level of interest both for total interest and for interest incurred only in respect of connected persons. This is recommended as an area for further research, if it is possible to draw this data from the original data from which the panel was constructed.

\section{$5 \quad$ Results and discussion}

\subsection{Analysis of funding structures: debt-to-equity ratios}

Debt-to-equity ratios calculated for the overall population rendered results that were significantly different from anticipated ratios. ${ }^{8}$ Further analysis revealed that, given the relatively low norm to be expected for these ratios, any observation with a higher ratio would have a disproportionate effect on the mean ratio. Two types of observation were identified:

1. Anomalies in the data for the purposes of a debt-to-equity analysis;

2. Items that had characteristics that could be expected and would therefore not be anomalies, but which would at the same time distort the mean ratios and therefore had to be further disaggregated.

The following observations, identified as anomalies for the reasons stated below, were excluded from the population for the purposes of the debt-to-equity ratio analysis:

Anomaly 1: Entities that reported a total equity amount ${ }^{9}$ equal to nil were excluded on the assumption that such entities were dormant entities. It is anticipated that an entity that is not dormant will have at least R1 equity. It is also not possible to calculate a debt-to-equity ratio where the denominator is nil.

\footnotetext{
${ }^{8}$ The mean debt-to-equity ratios for the categories of observations considered were 1 135:1 for foreign branches, 1 969:1 for entities other than foreign-held or foreign branches, and 11 967:1 for foreign-held entities.

${ }^{9}$ Total equity would represent the sum of share capital, share premium, and any other reserves (including retained earnings).
} 
Anomaly 2: Entities that had negative total liabilities were excluded, as this indicated that taxpayers might have misclassified the information reported as liabilities. A liability with a negative balance represents an asset rather than a funding instrument. If these items were to be included as funding instruments in a funding structure analysis, it would distort the results.

Anomaly 3: A number of entities with a debt-to-equity ratio of exactly -1 were excluded. During the analysis of the panel data, we identified that the accounting equation (i.e. total assets minus total liabilities should be equal to total equity) did not balance for all observations. For the purposes of the research, equity was calculated as the residual amount between the reported total assets and reported total liabilities for each observation. This resulted in a negative value being assigned to observations that only had liabilities. Given that this result clearly reflected an assumption used to overcome a shortcoming in the panel data, these observations were excluded.

The remaining population (excluding the anomalies) was disaggregated to separate it into categories of observations that would have a distortionary effect on the mean debt-to-equity ratio. These include a number of categories that could not reasonably be expected to render a debt-toequity ratio within the anticipated range, for various reasons set out below. The residual category represents observations viewed as normal entities (i.e. not falling within any of the exceptional categories identified) in respect of which a meaningful analysis of the level of debt funding for South African firms could be performed.

The categories into which the population was disaggregated are the following:

Exceptional category 1-items with negative total equity balance: An entity with a negative total equity amount is essentially only funded by debt. As such, a debt-to-equity ratio for these entities is extremely high and distorts the mean ratio, as the result is a negative debt-to-equity ratio.

Exceptional category 2-items with positive total equity balance and no non-current liabilities: The population contained a number of entities with no non-current liability balance. This category consisted of large entities (based on the total equity balance that consists mostly of accumulated retained earnings) that only had relatively small amounts of current liability (trade payables). It is anticipated that these entities are well-established entities that are funded by owners' capital and no significant external debt. This category also included entities that have low total equity balances, in relation to which any amount of current liability appears significant and therefore results in a high debt-toequity ratio. It is submitted that any debt-to-equity ratio based solely on current liabilities does not reflect the long-term funding structure of an entity. For this reason this category should be viewed separately.

Exceptional category 3-entities with total equity balances below R1 000: Entities in this category are either dormant, in which case the inclusion of the debt-to-equity ratio in the analysis would be of little value, or are effectively only funded by debt, given the absence of any significant equity. The figure of R1 000 was determined based on practical experience in relation to the incorporation of companies and the typical initial capital investment made. These entities differ from those included in the Anomaly 1 category, as the entities in this exception category had equity, as opposed to a nil equity for the entities in Anomaly category 1. The debt-to-equity ratio of these entities is not comparable with that of entities funded by a mix of debt and equity.

Normal entities: Any observations remaining after the disaggregation of the above exceptional items were classified as normal entities, in the sense that they did not fall into either an anomaly or an exceptional category for the purposes of the paper. The descriptive analysis was performed in respect of these entities. 
Table 3 describes the number of entities in each of the above four categories for all periods covered by the analysis. It is submitted that this information would be of value to policymakers, as it provides an indication of types of entities or circumstances that may exist and of which cognizance must be taken when drafting legislation in this regard. The potential importance of these categories is evident from the number of observations that fall into the respective categories.

Table 3: Breakdown of population of observations used to describe debt-to-equity ratios

\begin{tabular}{lccc}
\hline & $\begin{array}{c}\text { Foreign-held } \\
\text { companies }\end{array}$ & $\begin{array}{c}\text { South African } \\
\text { branches of foreign } \\
\text { companies }\end{array}$ & $\begin{array}{c}\text { Entities other than foreign- } \\
\text { held companies or South } \\
\text { African branches }\end{array}$ \\
\hline $\begin{array}{l}\text { Exceptional category 1-items with } \\
\text { negative total equity balance }\end{array}$ & 1074 & 2886 & 190455 \\
$\begin{array}{l}\text { Exceptional category 2-items with } \\
\text { positive total equity balance and no } \\
\text { non-current liabilities }\end{array}$ & 2353 & 3134 & 160547 \\
$\begin{array}{l}\text { Exceptional category 3-entities } \\
\text { with total equity balances below }\end{array}$ & 15 & & \\
$\begin{array}{l}\text { R1 000: } \\
\text { Normal entities } \\
\text { Total number of observations in } \\
\text { population (excluding anomalies) }\end{array}$ & $\mathbf{6 0 7 9}$ & 233 & 15011 \\
\hline
\end{tabular}

Source: authors' compilation from the panel data.

The mean debt-to-equity ratios for the normal entities in Table 3 for the respective categories of observations are presented in Table 4.

Table 4: Mean debt-to-equity ratios for normal entities

\begin{tabular}{lccc}
\hline & $\begin{array}{c}\text { Foreign-held } \\
\text { companies }\end{array}$ & $\begin{array}{c}\text { South African } \\
\text { branches of foreign } \\
\text { companies }\end{array}$ & $\begin{array}{c}\text { Entities other than foreign- } \\
\text { held companies or South } \\
\text { African branches }\end{array}$ \\
\hline Mean debt-to-equity ratio & $43.21: 1$ & $18.18: 1$ & $22.87: 1$ \\
\hline
\end{tabular}

Source: authors' compilation from the panel data.

The mean debt-to-equity ratios described in Table 4 suggest that foreign-held companies have a greater degree of debt funding in their capital structure than the other two categories. However, all of the above ratios far exceed the norms suggested for this ratio in the McGregor BFA database (ranging between 2:1 and 6:1 depending on the industry). Given the relatively low ratio suggested as the norm, any outlier will have a disproportionate effect on the mean ratio. To establish the effect of these outliers on the mean ratios, the mean debt-to-equity ratios in Table 4 were further divided into percentiles to describe their distribution. The information for the percentiles considered is provided in Table 5. 
Table 5: Mean debt-to-equity ratios for normal entities divided into percentiles

\begin{tabular}{lccc}
\hline & $\begin{array}{c}\text { Foreign-held } \\
\text { companies }\end{array}$ & $\begin{array}{c}\text { South African branches } \\
\text { of foreign companies }\end{array}$ & $\begin{array}{c}\text { Entities other than } \\
\text { foreign-held companies } \\
\text { or South African } \\
\text { branches }\end{array}$ \\
\hline $\begin{array}{l}\text { Mean debt-to-equity ratio } \\
\text { for normal entities }\end{array}$ & $43.21: 1$ & $18.18: 1$ & $22.87: 1$ \\
10th percentile & $0.16: 1$ & $0.21: 1$ & $0.19: 1$ \\
25th percentile & $0.4: 1$ & $0.6: 1$ & $0.55: 1$ \\
50th percentile & $1.09: 1$ & $1.8: 1$ & $1.6: 1$ \\
75th percentile & $3.24: 1$ & $6.21: 1$ & $5.02: 1$ \\
90th percentile & $10.09: 1$ & $19.5: 1$ & $17.11: 1$ \\
99th percentile & $219.52: 1$ & $228.93: 1$ & $228.73: 1$ \\
\hline
\end{tabular}

Source: authors' compilation from the panel data.

The data described in Table 5 suggests that the greater mean debt-to-equity ratio for foreign-held companies is merely the result of a small number of entities with extremely high debt-to-equity ratios that appear in the 90th percentile and upwards (or top decile). The overall trend suggested by the results in Table 5 is in fact that the foreign-held companies generally had a lower mean debt-to-equity ratio than the domestically owned companies, as illustrated in Figure 1.

Figure 1: Comparison of debt-to-equity ratios for percentiles up to the 75 th percentile

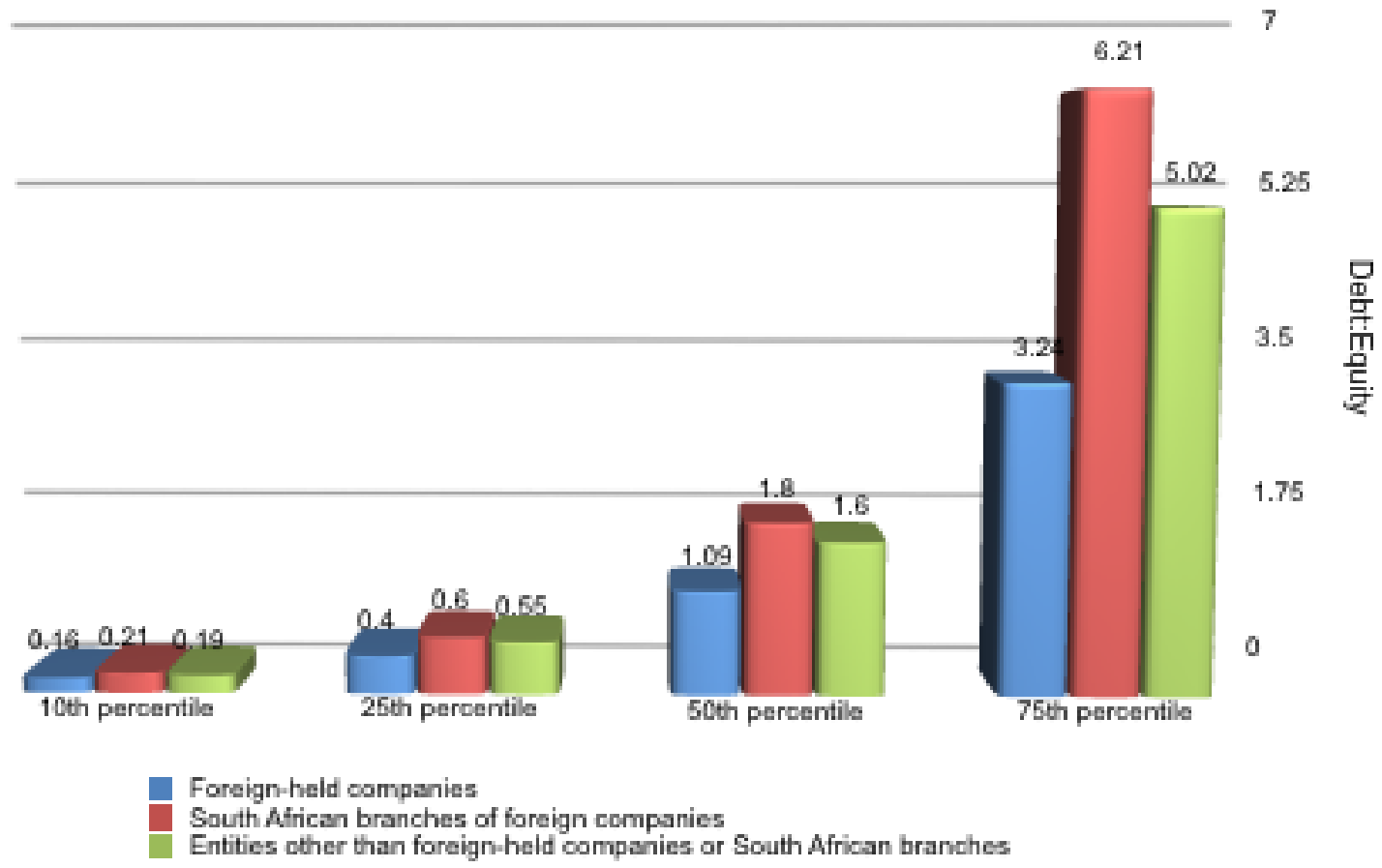

Source: authors' compilation from the panel data.

The categories of foreign-owned entities that appear to have a greater level of debt funding than the domestically owned companies are South African branches of foreign companies between the 75th and 90th percentiles. Given that the allocation of balance sheet items to branches or permanent establishments of foreign entities for the purposes of reporting on the South African income tax return is not prescribed by the Act or any similar authority, we are of the view that it would not be appropriate to read any significant finding into this observation. However, if the 
analysis of the interest coverage ratios, where guidelines exist regarding allocation of expenditure to permanent establishments, suggests a similar tendency, the capital structure observation may shed further light on that finding.

The relatively high debt-to-equity ratios suggested in the 90th percentile across all categories suggest that excessive levels of debt and/or a bias towards debt funding may exist for certain companies. This observation would in our view warrant further research to understand the characteristics of the entities in the 90th percentile. This information may be of value to policymakers when assessing the impact of an overall interest deduction that applies irrespective of whether the lender is a connected person or whether the interest is paid to a foreign lender or not.

In light of the lack of any significant tendency of the two categories of foreign-owned entities towards a greater degree of debt funding than the domestically owned category of companies, no further analysis of this ratio was performed.

\subsection{Analysis of the cost of funding: interest coverage ratios}

Similarly to the debt-to-equity ratios described in section 5.1 of this paper, the mean interest coverage ratio for the overall population rendered results that were significantly different from anticipated ratios. ${ }^{10}$ Further analysis revealed that this was caused by a number of factors, including negative ratios and entities with a low profit base compared with their net interest cost. Similarly to the analysis in section 5.1, certain categories of observations that had characteristics that would cause the interest coverage ratio to be different from the anticipated ratio were identified, and the population was therefore again disaggregated.

The population was disaggregated to separate it into categories of observations that would have a distortionary effect on the net interest-to-EBITDA ratio, and ultimately to produce a residual category of observations that could be viewed as normal entities (i.e. not falling within any of the exceptional categories identified) in respect of which meaningful analysis could be performed.

The categories into which the population was disaggregated are the following:

Exceptional category 1-observations with a negative interest-expense-to-EBITD A ratio: An entity will have a negative interest-to-EBITDA ratio if the denominator (EBITDA) is negative. An analysis of this category of entities revealed that this was the case for mainly two groups of entities. Firstly, an entity that borrows funds and on-lends this to earn interest income is likely to have a negative EBITDA (representing operating costs incurred) while its primary revenue source (interest income) is excluded from the EBITDA indicator. This scenario will arise if the entity acts as a conduit for funds. The second type of entity is one that incurs interest expenditure but does not have any operations income (turnover). The presumption exists that this class of entity is likely to be a start-up business that is incurring interest costs.

Exceptional category 2-observations with a positive interest-expense-to-EBITD $A$ ratio but negative total equity balance: The fact that an entity has a positive interest-to-EBITDA ratio indicates that the entity was profitable (in EBITDA terms) for the current period or tax year. However, the fact that the entity

\footnotetext{
${ }^{10}$ The mean net interest-to-EBITDA ratios for the categories of observations considered were 18 per cent for foreign branches, 21324 per cent for entities other than foreign-held or foreign branches, and -691 per cent for foreign-held companies.
} 
has a negative total equity balance indicates that the entity was at some stage in the past not profitable and therefore recorded accumulated losses that caused the total equity balance to be negative. The high interest cost incurred by these entities compared with the level of profitability would suggest that this entity is in a stage of recovery, and that the interest coverage ratios may therefore be distorted while this recovery is underway. However, these observations were clearly distinguishable based on the high interest coverage ratios.

Exceptional category 3-observations with a positive interest-expense-to-EBITD A ratio, positive where interest income exceeds interest expenditure: These entities are not in a net interest-paying position. The net interest-to-EBITDA ratios, which the OECD suggests should be used as a basis for interest deduction limitations, would therefore be negative and distort the overall view of the population. These entities were therefore excluded from the normal entities category. This category should include entities that do not have significant levels of debt, but that do have cash reserves. The observations included in this category are likely to overlap with the exceptional category 2 identified for the purposes of the debt-to-equity analysis.

Normal entities: Any observations remaining in the residual part of the population after excluding the above exceptional items were classified as normal entities. These entities represent entities with a positive net interest-cost-to-EBITDA ratio that has a positive total equity balance. The descriptive analysis was performed in respect of these entities.

Table 6 provides an overview of the composition of the population into the three categories explained above. Similarly to the views expressed in respect of the categories of entities in Table 3, it is submitted that this information would be of value to policymakers as it provides an indication of types of entities or circumstances that may exist for which future legislation in this regard may have to make provision. The relevance of these categories is evident from the number of observations that fall into the respective categories. It should be noted that when the total numbers of observations in Table 3 and Table 6 are compared, the difference is caused by entities that have a nil interest-to-EBITDA ratio. These entities may have some items on their balance sheets and are therefore included in Table 3, but do not have any income statement activity and are therefore not included in Table 6 . The significantly lower number of observations included in Table 6 corresponds with the description of the overall population of the observations in the data panel by Flowerday et al. (2016), who indicate that in excess of 300000 companies do not have taxable income. Table 6 only represents entities with some form of performance (profitability), whether this was positive or negative. 
Table 6: Breakdown of population of observations used to describe interest coverage ratios

\begin{tabular}{lccc}
\hline & $\begin{array}{c}\text { Foreign-held } \\
\text { companies }\end{array}$ & $\begin{array}{c}\text { South African } \\
\text { branches of } \\
\text { foreign } \\
\text { companies }\end{array}$ & $\begin{array}{c}\text { Entities other than } \\
\text { foreign-held } \\
\text { companies or South } \\
\text { African branches }\end{array}$ \\
\hline $\begin{array}{l}\text { Exceptional category 1-observations with } \\
\text { a negative interest-expense-to-EBITDA } \\
\text { ratio }\end{array}$ & 1586 & 970 & 66612 \\
$\begin{array}{l}\text { Exceptional category 2-observations with } \\
\begin{array}{l}\text { a positive interest-expense-to-EBITDA } \\
\text { ratio but negative total equity balance }\end{array}\end{array}$ & 408 & 495 & 37989 \\
$\begin{array}{l}\text { Exceptional category 3-observations with } \\
\text { a positive interest-expense-to-EBITDA } \\
\text { ratio, positive where interest income } \\
\text { exceeds interest expenditure }\end{array}$ & 1390 & & \\
$\begin{array}{l}\text { Normal entities } \\
\text { Total number of observations in } \\
\text { population }\end{array}$ & 1377 & 632 & 45187 \\
\hline
\end{tabular}

Source: authors' compilation from the panel data.

The mean interest coverage ratios for the normal entities category are provided in Table 7 . This forms the basis for the subsequent analysis of interest coverage ratios in the remainder of this paper.

Table 7: Mean interest coverage ratios for normal entities

\begin{tabular}{ccccccc}
\hline & Foreign-held companies & $\begin{array}{c}\text { South African branches of } \\
\text { foreign companies }\end{array}$ & $\begin{array}{c}\text { Entities other than foreign- } \\
\text { held companies or South } \\
\text { African branches }\end{array}$ \\
\cline { 2 - 4 } & Gross & Net interest: & $\begin{array}{c}\text { Gross } \\
\text { interest: }\end{array}$ & $\begin{array}{c}\text { Net interest: } \\
\text { EBITDA }\end{array}$ & $\begin{array}{c}\text { Gross } \\
\text { interest: }\end{array}$ & $\begin{array}{c}\text { Net interest: } \\
\text { EBITDA }\end{array}$ \\
interest: & EBITDA & $\begin{array}{c}\text { EBITDA } \\
\text { EBITDA }\end{array}$ & & & EBITDA & \\
Mean ratio & $290 \%$ & $58 \%$ & $176 \%$ & $38 \%$ & $70 \%$ & $53 \%$
\end{tabular}

Source: authors' compilation from the panel data.

The mean ratios in Table 7 illustrate that the difference between using a gross interest ratio and a net interest ratio is significant. In light of the fact that the current legislation and OECD proposals are based on net interest ratios, the remainder of the analysis was performed based on the net interest-to-EBITDA ratio.

At face value the net interest-to-EBITDA ratio for foreign-held companies is higher than the same ratio for domestically owned companies (approximately 10 per cent higher). In order to gain an understanding of this finding, the normal entities category was divided into percentiles to describe the distribution of the mean across the entities, in Table 8. 
Table 8: Distribution of mean net interest-to-EBITDA ratios for normal entities

\begin{tabular}{lccc}
\hline & $\begin{array}{c}\text { Foreign-held } \\
\text { companies }\end{array}$ & $\begin{array}{c}\text { South African branches } \\
\text { of foreign companies }\end{array}$ & $\begin{array}{c}\text { Entities other than } \\
\text { foreign-held companies } \\
\text { or South African } \\
\text { branches }\end{array}$ \\
\hline $\begin{array}{l}\text { Mean net interest-to- } \\
\text { EBITDA ratio }\end{array}$ & $58 \%$ & $38 \%$ & $53 \%$ \\
10th percentile & $0.3 \%$ & $0.4 \%$ & $0.4 \%$ \\
25th percentile & $1.9 \%$ & $2.7 \%$ & $3.1 \%$ \\
50th percentile & $9.3 \%$ & $10.4 \%$ & $11.2 \%$ \\
75th percentile & $33 \%$ & $29 \%$ & $31 \%$ \\
81.25th percentile & $43 \%$ & $41 \%$ & $41 \%$ \\
87.5th percentile & $66 \%$ & $62 \%$ & $59 \%$ \\
93.75th percentile & $120 \%$ & $98 \%$ & $93 \%$ \\
95th percentile & $170 \%$ & $101 \%$ & $100 \%$ \\
99th percentile & $1173 \%$ & $422 \%$ & $404 \%$ \\
\hline
\end{tabular}

Source: authors' compilation from the panel data.

In addition to describing the distribution of the mean net interest-to-EBITDA ratios, the mean interest-to-EBITDA ratios for various sizes of businesses were also disaggregated. In order to present more meaningful information, the respective mean ratios were presented for a number of percentiles in each category. Turnover was used as an indicator of the size of the business. The thresholds used were R1 million (based on the threshold to qualify for turnover tax) and R20 million (based on the threshold to be classified as a small business corporation in terms of Section $12 \mathrm{E}$ of the Act). The results of this disaggregation are provided in Table 9.

Table 9: Disaggregation of mean net interest-to-EBITDA ratios for normal entities according to entity size

\begin{tabular}{|c|c|c|c|}
\hline & $\begin{array}{l}\text { Foreign-held } \\
\text { companies }\end{array}$ & $\begin{array}{l}\text { South African branches } \\
\text { of foreign companies }\end{array}$ & $\begin{array}{c}\text { Entities other than } \\
\text { foreign-held companies } \\
\text { or South African } \\
\text { branches }\end{array}$ \\
\hline $\begin{array}{l}\text { Mean net interest-to- } \\
\text { EBITDA ratio }\end{array}$ & $58 \%$ & $38 \%$ & $53 \%$ \\
\hline Turnover < R1 million & $442 \%(25)$ & $117 \%(68)$ & $199.7 \%(6$ 894) \\
\hline 50th percentile & $57 \%$ & $74 \%$ & $58 \%$ \\
\hline 75th percentile & $306 \%$ & $100 \%$ & $98 \%$ \\
\hline 90th percentile & $1313 \%$ & $238 \%$ & $151 \%$ \\
\hline $\begin{array}{l}\text { Turnover > R 1million, } \\
<\text { R20 million }\end{array}$ & $91 \%(216)$ & $34 \%(1111)$ & $43 \%(85824)$ \\
\hline 50th percentile & $23 \%$ & $10 \%$ & $10.5 \%$ \\
\hline 75th percentile & $53 \%$ & $26 \%$ & $27.8 \%$ \\
\hline 90th percentile & $119 \%$ & $56 \%$ & $60.2 \%$ \\
\hline Turnover > R20 million & $43 \%\left(\begin{array}{lll}1 & 136\end{array}\right)$ & $29 \%(291)$ & $45 \%(22700)$ \\
\hline 50th percentile & $8 \%$ & $8.5 \%$ & $9.8 \%$ \\
\hline 75th percentile & $28 \%$ & $27 \%$ & $25 \%$ \\
\hline 90th percentile & $72 \%$ & $133 \%$ & $57 \%$ \\
\hline
\end{tabular}

Source: authors' compilation from the panel data. 
The basis level of interest limitation in Section $23 \mathrm{M}$ is set at 40 per cent, ${ }^{11}$ which may be adjusted upwards or downwards depending on the repurchase rate. The OECD proposed a limit of between 10 and 30 per cent. Previous statistics released by Statistics South Africa indicated that interest-toEBITDA ratios ranged between 10 and 15 per cent. It is submitted that Table 8 contributes to the understanding of the levels of net interest to EBITDA of South African companies. This information would be of value if policymakers were to consider lowering the threshold to be in line with the level of interest suggested by Statistics South Africa, which appears to be in line with the OECD recommendations. Table 8 indicates that approximately 50 per cent of normal companies have net interest-to-EBITDA ratios of approximately 10 per cent or lower. However, companies between the 50th and 80th percentiles have net interest-to-EBITDA ratios ranging between 10 per cent and 40 per cent. This would suggest that the current level of interest limitation threshold is likely to be appropriate in the South African context, given the large number of taxpaying companies that have interest coverage ratios in the range between the OECD's suggested threshold (10 per cent) and the current South African threshold (calculated from a basis rate of 40 per cent). A reduction in the threshold will impact on approximately 25 per cent of taxpaying South African entities. A further important observation is that up to the level of a net interest-to-EBITDA ratio of approximately 40 per cent there is no significant difference between the mean ratios of the three categories of entities. No clear evidence of manipulation of interest cost is suggested by this finding.

The information in Table 9 suggests that this observation holds true for entities with turnover exceeding the R1 million threshold (with the exception of foreign-held companies in the bracket between R1 million and R20 million, discussed below). It appears that the ratio for smaller companies (turnover of less than R1 million) is significantly higher. It is submitted that in both a domestic and a cross-border context, an entity with a turnover of less than R1 million is small and is likely to be a start-up operation. This should explain to a large degree the relatively high cost of interest to EBITDA.

Comparison of the level of interest to EBITD $A$ between the categories of entities

A comparison of the distribution of the mean shows that the mean ratios for South African branches of foreign companies and domestically owned companies remain at fairly similar levels across all the percentiles presented. This finding is in contrast with the indication that certain South African branches of foreign companies may have a greater preference for debt funding than other entities considered, as was suggested in the debt-to-equity analysis. As indicated in the debt-toequity analysis, the finding in relation to South African branches of foreign companies may only exist due to arbitrary allocations of items of debt or equity to such branches in order to complete the tax return (given that this is not a separate legal entity). It may, however, be indicative of a real risk of thin capitalization and excessive interest allocations. The findings in relation to the level of interest to EBITDA for such branches would suggest that the former is more likely to be the case, as the interest-to-EBITDA ratios were comparable with domestically owned companies. Therefore that particular finding in relation to the debt-to-equity analysis was not further explored.

However, the mean ratio for foreign-held companies starts to increase relative to the other two groups from the 75th percentile, as illustrated in Figure 2. The difference between the mean ratios

\footnotetext{
${ }^{11}$ Input B into the formula in Section $23 \mathrm{M}(3)(\mathrm{b})$.
} 
for this group and the other two categories of entities increases more significantly for each percentile greater than the 75 th percentile presented. It is submitted that this trend identified for foreign-held entities may be an indication of more aggressive tax behaviour in the form of high interest deductions. It is further submitted that this is the area that BEPS actions should be aimed at.

Figure 2: Comparison of net interest-to-EBITDA ratios across all percentiles

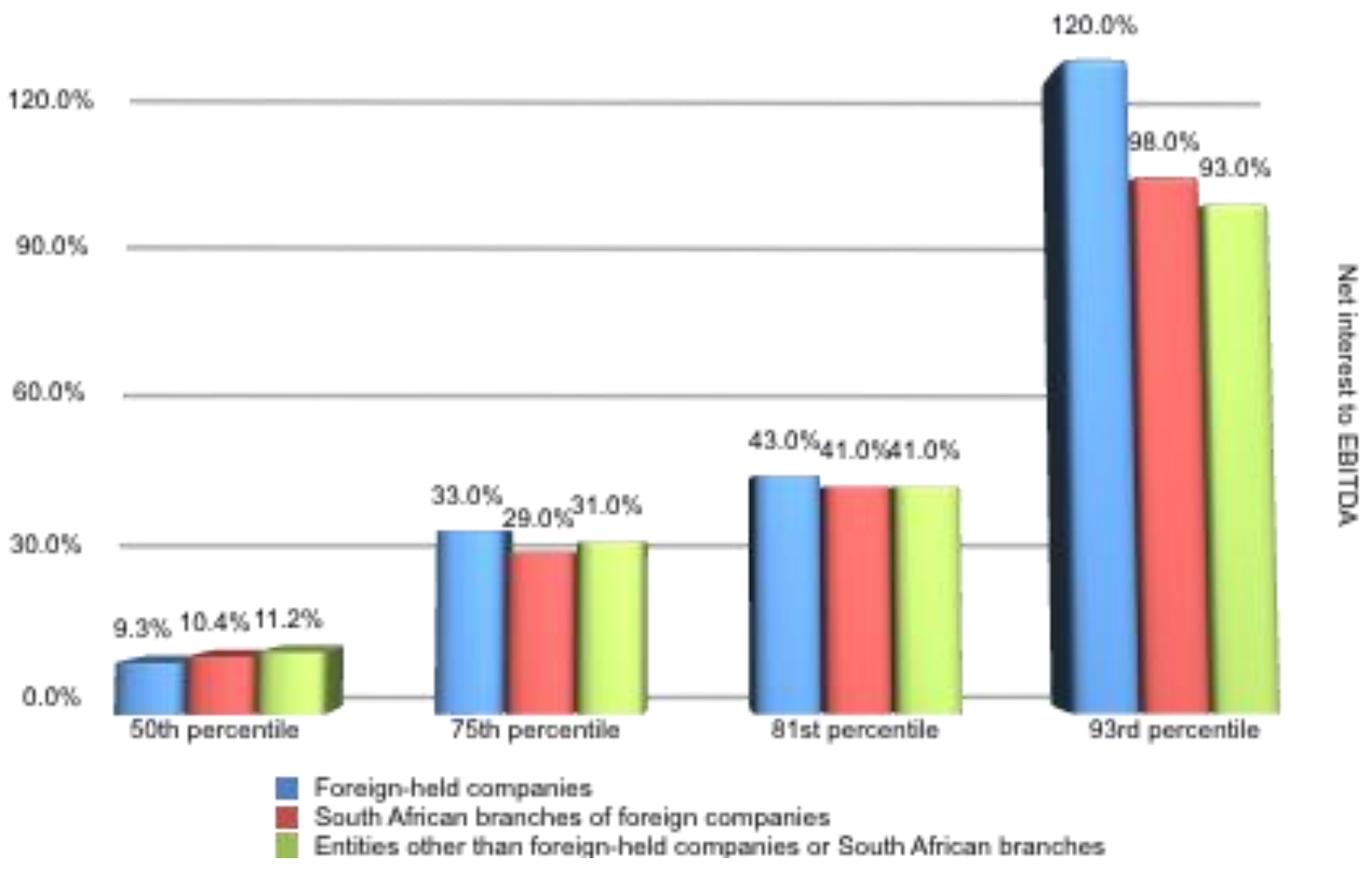

Source: authors' compilation from the panel data.

The information in Table 9, as illustrated in Figure 3, shows that the mean net interest to EBITDA for foreign-held companies in the turnover bracket between R1 million and R20 million is significantly higher than the other two groups of entities across all percentiles. 
Figure 3: Net interest-to-EBITDA ratios for companies with turnover between R1 million and R20 million

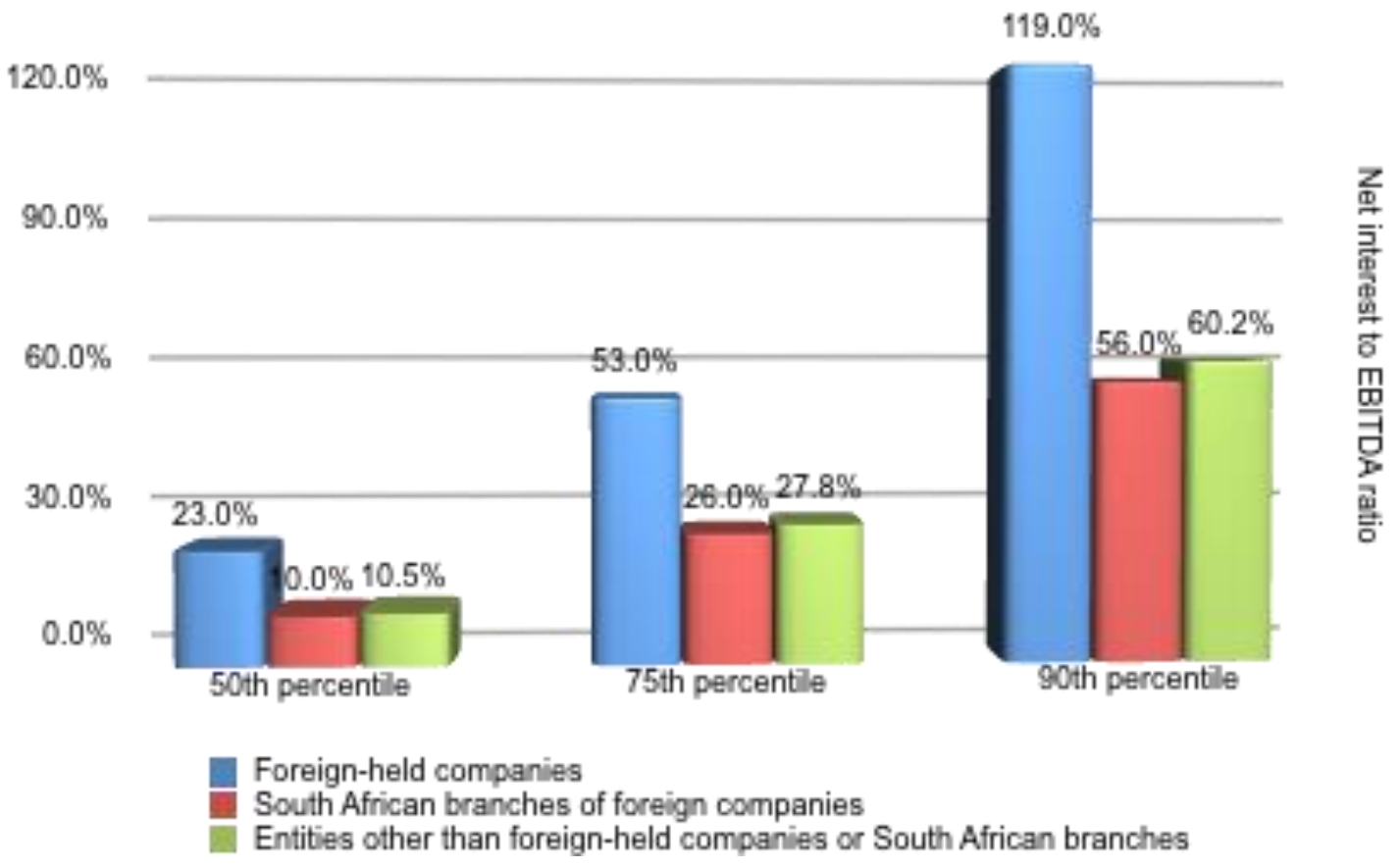

Source: authors' compilation from the panel data.

In the context of foreign companies establishing their operations in South Africa, a turnover of R20 million is still relatively low. It is therefore submitted that the high ratios in this turnover bracket may be a reflection of this fact, rather than of possible aggressive planning behaviour.

The trend in the ratios of the larger companies in Table 9 and the upward trend in Table 8, as illustrated by Figure 4, appear to be similar for companies falling within the 75 th percentile and upwards. 
Figure 4: Trend in net interest-to-EBITDA ratio for 75th percentile and upwards in companies with turnover exceeding R20 million

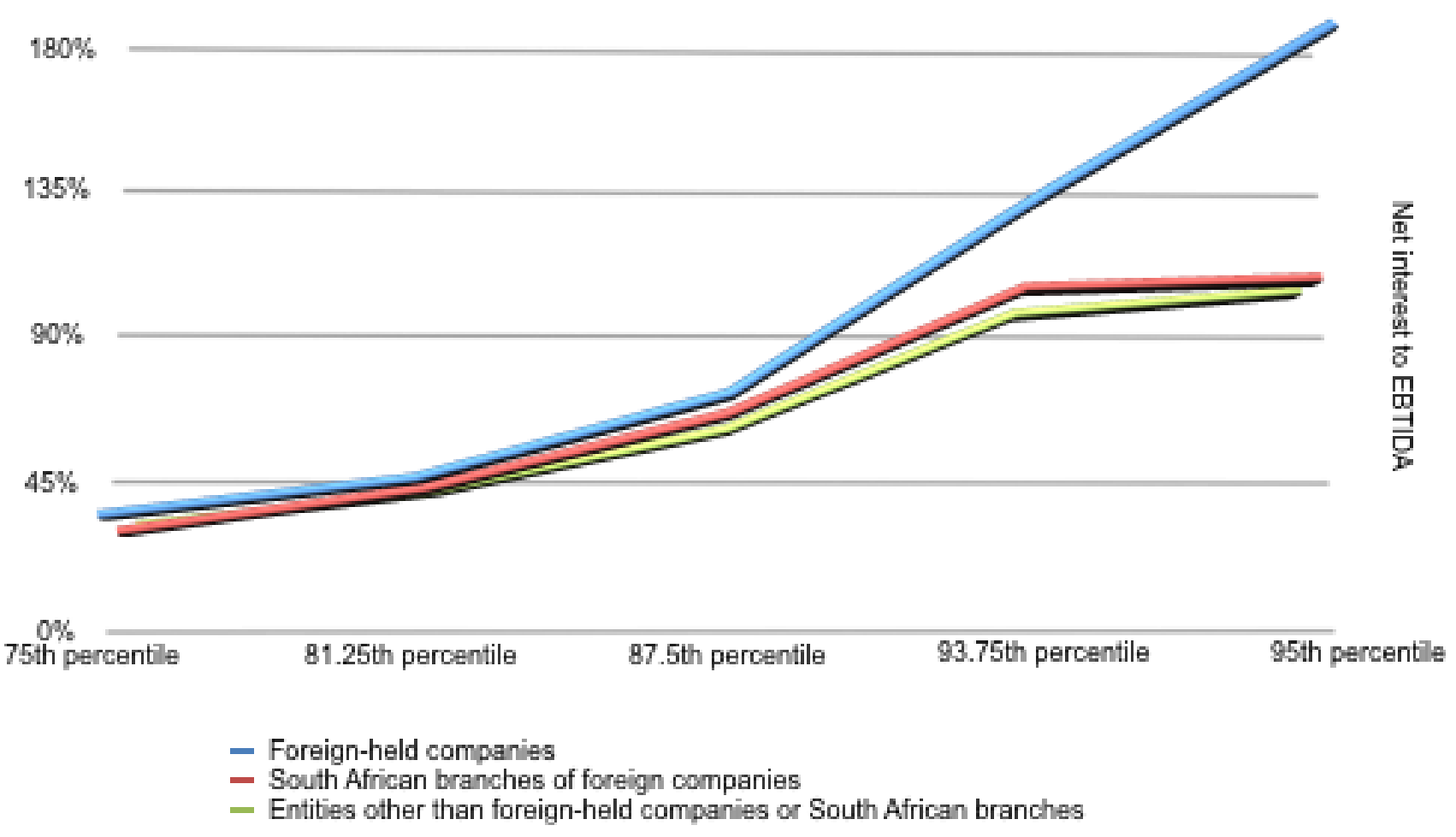

Source: authors' compilation from the panel data.

It is therefore concluded that the main finding from the data described in Tables 8 and 9 is that foreign-held entities, especially larger entities with a turnover of more than R20 million, have a higher net interest-to-EBITDA ratio than the other groupings of entities considered. In order to gain an understanding of these entities, entities in the 75th percentile and upwards are further described in the remainder of this paper.

Description of entities in the 75 th percentile and upwards based on net interest-to-EBITD $A$ ratios

The further description of entities in the 75th percentile and upwards was done on the basis of the size of the entities in this group, the industry in which the entities were involved, and the country in which the controlling group company was located for foreign-held companies.

Table 10 shows the number of entities in the 75th percentile and upwards in each of the three size categories used earlier. 
Table 10: Composition of companies in the 75th percentile and upwards by size

\begin{tabular}{lccc}
\hline & $\begin{array}{c}\text { Foreign-held } \\
\text { companies }\end{array}$ & $\begin{array}{c}\text { South African branches } \\
\text { of foreign companies }\end{array}$ & $\begin{array}{c}\text { Entities other than } \\
\text { foreign-held companies } \\
\text { or South African } \\
\text { branches }\end{array}$ \\
\hline Turnover < R1 million & 14 & 56 & 4816 \\
$\begin{array}{l}\text { Turnover > R 1 million, } \\
<\text { R20 million }\end{array}$ & 82 & 245 & 19409 \\
$\begin{array}{l}\text { Turnover > R20m } \\
\begin{array}{l}\text { Total number of } \\
\text { observations in } \\
\text { population }\end{array}\end{array}$ & 249 & 67 & 4630 \\
\hline
\end{tabular}

Source: authors' compilation from the panel data.

Table 10 shows that the majority of foreign-held companies in the 75 th percentile and upwards are larger companies.

For the purposes of compiling Table 11, the contribution of each industry sector to the whole population of each group of companies (i.e. foreign-held companies, South African branches of foreign companies, and domestically owned companies) was determined based on the number of entities across all percentiles. The composition of the entities included in the 75 th percentile and upwards was similarly determined. Following this, the relative change in contribution of each industry sector from the contribution to the whole population to the contribution of the group of entities in the 75 th percentile and upwards was considered. The change in contribution provides an indication of industries that have more entities present in the 75th percentile than across all percentiles. This is an indication of the industries where the high net interest-to-EBITDA ratios indicated in Tables 8 and 9 are particularly prevalent. Table 11 presents industries with a greater presence in the 75th percentile upwards than across all percentiles, sorted according to increases for foreign-held companies.

Table 11: Percentage changes in contributions of industries to the 75th percentile and upwards compared with their contribution across all percentiles

\begin{tabular}{lccc}
\hline & $\begin{array}{c}\text { Foreign-held } \\
\text { companies }\end{array}$ & $\begin{array}{c}\text { South African branches } \\
\text { of foreign companies }\end{array}$ & $\begin{array}{c}\text { Entities other than } \\
\text { foreign-held companies } \\
\text { or South African } \\
\text { branches }\end{array}$ \\
\hline $\begin{array}{l}\text { Real-estate activities } \\
\text { Financial and insurance }\end{array}$ & 9.26 & 15.46 & 16.82 \\
activities & 4.40 & -1.86 & 0.82 \\
Agriculture & 2.98 & -0.10 & 1.19 \\
Accommodation and food & 0.93 & 0.92 & 0.41 \\
service activities & & & -1.58 \\
$\begin{array}{l}\text { Other service activities } \\
\text { Administrative and }\end{array}$ & 0.29 & -2.67 & -0.53 \\
support service activities & 0.01 & 0.04 & \\
\hline
\end{tabular}

Source: authors' compilation from the panel data.

Table 11 shows that the three industries that have an increased presence in the 75th percentile and upwards, when compared with the contribution across all percentiles, are real-estate activities, financial and insurance activities, and agriculture. The percentage changes are shown in Figure 5. 
Figure 5: Change in contribution of certain industries from the overall population to 75th percentile and upwards (based on net interest-to-EBITDA ratios)

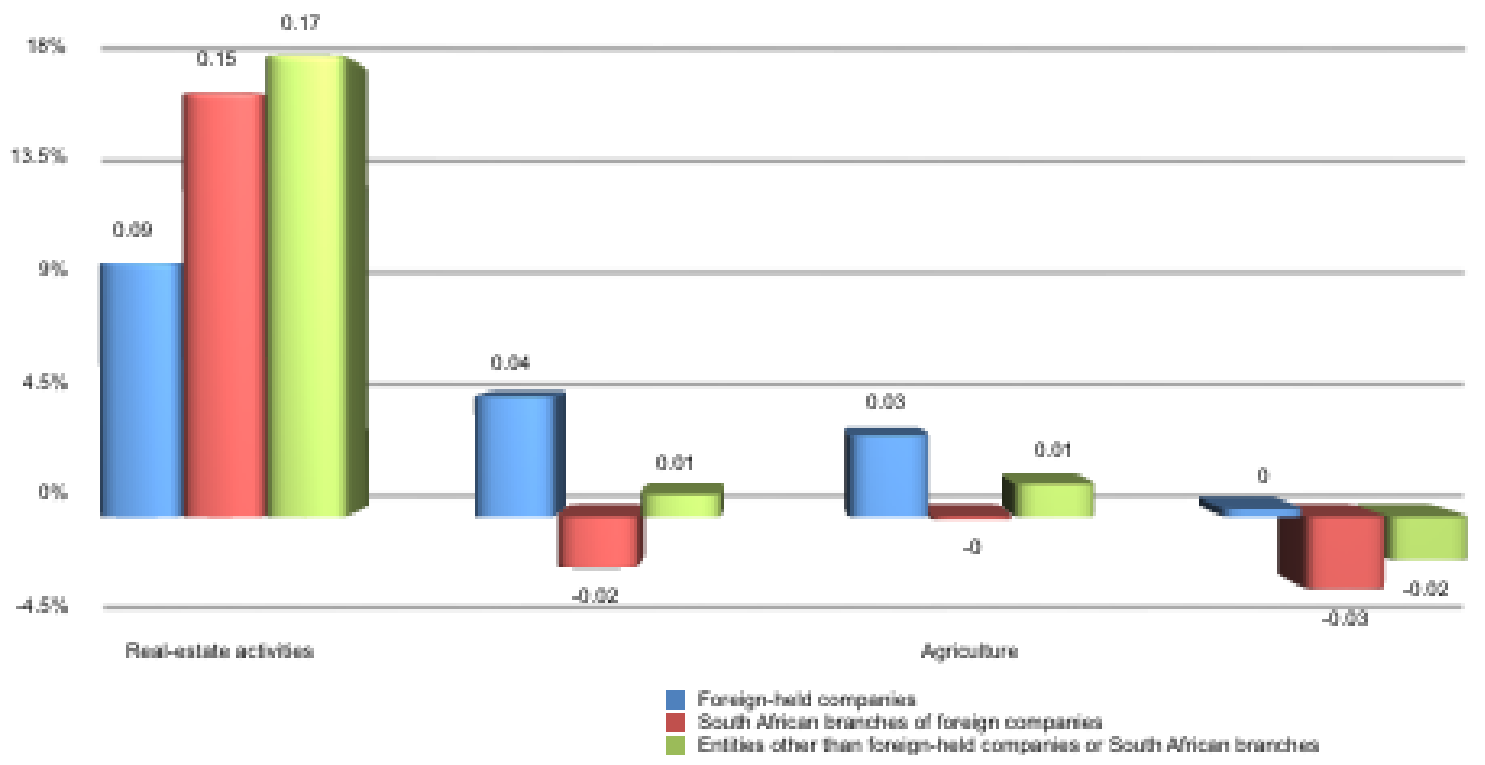

Source: authors' compilation from the panel data.

The entities in the financial and insurance activities industry have special characteristics that need to be taken into account to explain their contribution to the higher mean net interest-to-EBITDA ratio from the 75 th percentile upwards. Real-estate activities and agriculture are both capitalintensive sectors, which may explain their increased presence in the higher ratio brackets. The value of this information is that these sectors may require special consideration by policymakers when it comes to interest deduction limits.

Lastly, the countries from which investment is made into South Africa in the form of the establishment of foreign-held entities were considered. Table 12 provides an overview of the top 10 countries from which such investment is made.

Table 12: Top 10 countries from which investment is made into South African foreign-held companies (by number of entities)

\begin{tabular}{lc}
\hline & $\begin{array}{c}\text { All foreign-held entities (normal } \\
\text { entities): contribution of entities } \\
\text { ultimately held from the country } \\
\text { of total foreign-held entities (\%) }\end{array}$ \\
\hline United States of America & 16.27 \\
Germany & 11.91 \\
South Africa & 4.21 \\
Great Britain & 8.79 \\
Switzerland & 4.21 \\
Mauritius & 3.05 \\
The Netherlands & 6.1 \\
British Virgin Islands & 3.12 \\
Japan & 2.54 \\
Canada & 1.6 \\
\hline
\end{tabular}

Source: authors' compilation from the panel data.

Table 13 provides an indication of the change in contribution to total investment by jurisdiction (based on the number of entities) from all percentiles to the 75 th percentile and upwards. This 
analysis would provide insight into companies from certain jurisdictions with a greater presence in the 75th percentile and upwards. This data is illustrated in Figure 6.

Table 13: Top 10 jurisdictions that contribute more investment in South African subsidiaries in the 75th percentile and upwards than across all percentiles (contribution by number of entities)

\begin{tabular}{lc}
\hline & $\begin{array}{c}\text { Change in \% investment from all } \\
\text { percentiles to the 75th percentile } \\
\text { and upwards (\% change) }\end{array}$ \\
\hline South Africa & 4.21 \\
Mauritius & 3.05 \\
Switzerland & 4.21 \\
Canada & 1.6 \\
Guinea Bissau & 1.6 \\
Namibia & 0.73 \\
British Virgin Islands & 3.12 \\
Cyprus & 1.16 \\
Guernsey & 0.65 \\
Sweden & 1.82 \\
\hline
\end{tabular}

Source: authors' compilation from the panel data.

Figure 6: Top 10 jurisdictions according to increase in contribution to 75th percentile and upwards compared with contribution to overall population (based on number of entities)

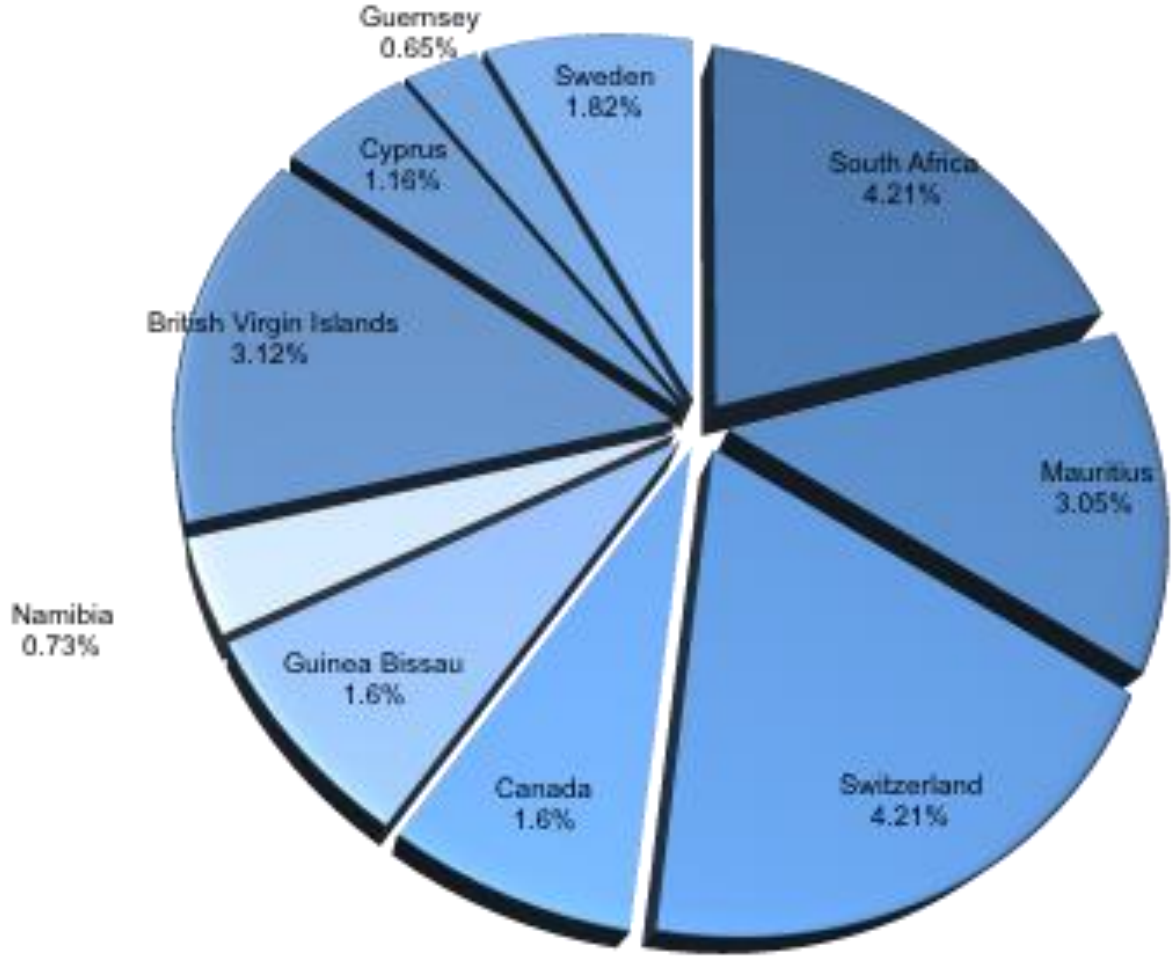

Source: authors' compilation from the panel data.

Table 13 (and Figure 6) suggests that a number of lower-tax jurisdictions or jurisdictions that may provide certain tax benefits for investors have a greater presence in the 75th percentile and upwards. This may support the earlier observation that the entities in this percentile may be involved in aggressive tax behaviour. It is recommended that further research be performed in relation to the specific foreign-held companies that appear in the 75th percentile and upwards to 
determine whether further indicators of aggressive behaviour can be identified. In addition, such research would further assist in identifying industries, possibly those indicated in Table 11, where such behaviour is not present despite high net interest-to-EBITDA ratios.

\subsection{Relationship between economic contribution and funding structure}

The findings reported in Tables 8 and 9 suggest that foreign-held companies that have significantly higher levels of net interest to EBITDA, and that may potentially be involved in aggressive tax behaviour, will appear in the 75th percentile and upwards if the normal entities are divided into percentiles based on net interest-to-EBITDA ratios. It is submitted that irrespective of the economic contribution of such entities, an interest limitation threshold of greater than 40 per cent would not be justifiable due to the profit shifting risk this could pose. For this reason, an in-depth analysis of the economic contribution of such foreign-held companies, other than the analysis already performed for the purposes of section 5.2, would not add any significant contribution to the findings or arguments put forward in this paper.

\section{Summary of main findings and conclusion}

In summary, the descriptive analysis of the data contained in the CIT-IRP5 Panel Data in relation to observations where taxpayers used the ITR14 submitted tax returns in the ITR14 format revealed the following:

- From a capital funding perspective, there is no clear indication of a greater preference for debt compared with equity funding by foreign-held companies or South African branches of foreign entities compared with domestically owned entities.

- The mean net interest-to-EBITDA ratio for entities up to the 75th percentile does not differ significantly among the three categories of entities considered. The net interest-to-EBITDA ratios for these entities up to the 75th percentile range are between nil and 33 per cent. However, from the 75th percentile upwards the mean net interest-to-EBITDA ratio increases significantly more for foreign-held companies.

The analysis further indicated that:

- This trend is likely to be caused by ratios of larger entities (turnover exceeding R20 million).

- Approximately 80 per cent of the taxpaying companies in South Africa have a net EBITDA ratio of around 40 per cent or less. Approximately 30 per cent of the population falls within the net interest-to-EBITDA range between 10 and 40 per cent, and would be affected by a decrease in the interest deduction limitation threshold. It is submitted that the basis rate of 40 per cent for the limitation under Section 23M appears to be appropriate.

- The number of entities in the 75th percentile and upwards includes a greater proportion of companies involved in real-estate and agricultural activities than the overall population of foreign-held companies considered. These sectors therefore appear to have higher net interestto-EBITDA ratios than other sectors. A similar trend exists for entities in the financial services and insurance activity sector. However, entities in this sector may have certain characteristics that need to be taken into account before it is possible to express further views on the implications of this trend.

- The proportionate representation of foreign-held companies owned by controlling companies situated in a number of low-tax jurisdictions (including Mauritius, the British Virgin Islands, 
Cyprus, and Guernsey) is relatively higher from the 75th percentile upwards than for the overall population of foreign-held companies.

In light of the high levels of net interest-to-EBITDA ratios at the 75 th percentile and upwards where the above trends were identified, there was no value to be gained from determining the economic contributions of the foreign-held companies in the 75th percentile and upwards, as an increase in the threshold determined from a base rate of 40 per cent up to levels of 80 per cent or more would not serve the purpose of countering base erosion and profit shifting. Therefore no economic contribution analysis for the foreign-held companies in the 75th percentile and upwards was performed.

\section{$7 \quad$ Limitations and areas for further research}

The results described in this paper are subject to a number of limitations, as indicated in the discussion. These limitations present an opportunity for further research to be performed using the panel data.

- Firstly, the indicator for entities that have a foreign controlling group company was only included in the ITR14 return. The analysis can be extended if it is possible to combine a number of indicators in a manner such that the status indicated on the ITR14 return can be imputed accurately to earlier periods for which a return was submitted using the IT14 return.

- The data available in the panel only allowed an analysis of total debt (in relation to capital structure ratios) and total interest (in relation to the interest coverage ratios). Ideally, separate analyses should be performed in respect of the level of interest calculated for both total interest and interest incurred only in respect of connected persons. This is an area to improve the results of the research if it is possible to obtain this information from the original data from which the panel was constructed.

- It is recommended that further research be performed by analysing the characteristics of the individual foreign-held companies that appear in the 75th percentile and upwards to determine whether further indicators of aggressive behaviour can be identified. Such research would further assist in identifying industries, possibly those indicated in Table 11, where such behaviour is not present despite high net interest-to-EBITDA ratios.

- The effect of using accounting data, as opposed to tax data, was considered for all EBITDA ratios. A comparison of the EBITDA amounts calculated using accounting and tax data respectively was also prepared. The comparison between EBITDA calculated using tax and accounting data showed that for both South African branches of foreign entities and domestically owned companies, EBITDA calculated using tax and accounting data did not differ materially for at least 80 per cent of the population, with some exceptions at the outer ends of the population in both directions (i.e. accounting EBITDA exceeding tax EBITDA, and in other instances, tax EBITDA exceeding accounting EBITDA). The variance was more notable in the case of foreign-held companies. Further research to gain an understanding of the adjustments that cause this variance would be of value, given that Section $23 \mathrm{M}$ (or any other tax legislation) would use a measure of EBITDA calculated using tax data. 


\section{References}

Barnes, P. (2014). 'Limiting Interest Deductions'. Papers on Selected Topics in Protecting the Tax Base of Developing Countries. New York: United Nations

Buettner, T., M. Overesch, U. Schreiber, and G. Wamser (2012). 'The Impact of ThinCapitalization Rules on the Capital Structure of Multinational Firms'. Journal of Public Economics, 96: 930-8.

Buettner, T., M. Overesch, and G. Wamser (2016). 'Restricted Interest Deductibility and Multinationals' Use of Internal Debt Finance'. International Tax and Public Finance, 23: 785-97.

Department: Trade and Industry (2016). 'Media Statement: Inter-Ministerial Committee on Investment Promotion Appointed'. Available at: www.thedti.gov.za/editmedia.jsp?id=3629 (accessed 23 January 2017).

Els, G., E. Du Toit, P. Erasmus, L. Kotzé, S. Ngwenya, K. Thomas, and S. Viviers (2010). Corporate Finance: A South African Perspective. Cape Town: Oxford University Press.

Flowerday, W., F. Kreuser, and T. Naughtin (2016). 'SARS-NT Firm Level Data Project: A Very Short Introduction to the CIT-IRP5 Panel Data'. Working Paper. Helsinki: UNU-WIDER.

Gajewksi, D. (2013) 'Tax-related and Economic Consequences of Selecting the Method of Debt Financing of Companies'. Contemporary Economics, 7(2): 77-83

Giacometti, P., and P. Meloni (2008). 'Italy Unveils New Interest Barrier Rules'. International Tax Review: Capital Markets, 13-16.

Gopalan, R., R. Nanda, and A. Seru (2007). 'Affiliated Firms and Financial Support: Evidence from Indian Business Groups'. Journal of Financial Economics, 86: 759-95.

Haufler, A., and M. Runkel (2012). 'Firms' Financial Choices and Thin Capitalization Rules under Corporate Tax Competition'. European Economic Review, 56: 1087-103.

Hemmelgarn, T., and G. Nicodème (2010). 'The 2008 Financial Crisis and Taxation Policy'. Taxation Papers: Working Paper 20. Brussels: European Commission.

Khumalo, T. (2015). 'Thin Capitalisation: An Analysis of the Application of the Amended Section 31(3) of the Income Tax Act No. 58 of 1962'. Magister Commercii in Accounting. Vanderbijlpark: North-West University.

Knauer, T., and F. Sommer (2012) 'Interest Barrier Rules as a Response to Highly Leveraged Transactions'. Review of Accounting and Finance, 11(2): 206-32.

Langedijk, S., G. Nicodème, A. Pagano, and A. Rossi (2014). 'Debt Bias in Corporate Taxation and the Costs of Banking Crises in the EU'. Taxation Papers: Working Paper 50. Available at:

ec.europa.eu/taxation_customs/resources/documents/taxation/gen_info/economic_analy sis/tax_papers/taxation_paper_50.pdf (accessed 25 February 2016).

Lloyd, G. (2012). 'Moving Beyond the Crisis: Strengthening Understanding of How Tax Policies Affect the Soundness of Financial Markets'. In J.S. Alsworth and A. Giampaolo (eds), Taxation and the Financial Crisis. Oxford: Oxford University Press.

Mardan, M. (2013). 'The Effects of Thin Capitalization Rules Where Firms are Financially Constrained'. Munich: CESfio.

Marino, T., and M. Russo (2008). 'Italian Restyling of Interest Deduction Rules: The Amendments of the Italian Finance Bill for 2008'. Intertax, 36(5): 204-10. 
Miesel, V.H., H.H. Higinbotham, and C.W. Yi (2003). 'International Transfer Pricing: Practical Solutions for Intercompany Pricing-Part II'. Internal Tax Journal, 29: 1-41.

Myers, S.C., and N.S. Majluf (1984). 'Corporate Financing and Investment Decisions When Firms Have Information That Investors Do Not Have'. Working Paper w1396. Cambridge, MA: National Bureau of Economic Research.

National Treasury (2013). 'Explanatory Memorandum on the Taxation Laws Amendment Bill 2013'. Pretoria: SARS.

National Treasury (2014a). 'Draft Response Document from National Treasury and SARS'. Presented to SCOF. Pretoria: SARS.

National Treasury (2014b). 'Explanatory Memorandum on the Taxation Laws Amendment Bill 2014 (B13-2014)’. Pretoria: SARS.

National Treasury (2016). 'Budget Review 2016’. Pretoria: SARS.

OECD (2013). Addressing Base Erosion and Profit Shifting. Paris: OECD Publishing. Available at: dx.doi.org/10.1787/9789264192744-en (accessed 23 January 2017).

OECD (2015). Limiting Base Erosion Involving Interest Deductions and Other Financial Payments, Action 4-2015 Final Report. Paris: OECD Publishing. Available at: dx.doi.org/10.1787/9789264241176-en (accessed 23 January 2017).

Saparoea, A.V. (2009). 'Optimizing the Interest Deduction Rules: A Never-Ending Story'. European Taxation, 49(1): 3-10.

Shackleford, D.A., D.N. Shaviro, and J. Slemrod (2010). 'Taxation and the Financial Sector'. National Tax Journal, 63(4): 781-806.

Shaviro, D. (2009). 'Internationalization of Income Measures and the US Book-Tax Relationship'. National Tax Journal, 62(1): 155-167.

South African Government (2016). 'President Jacob Zuma: State of the Nation Address 2016'. Available at: www.gov.za/speeches/president-jacob-zuma-state-nation-address-2016-11-feb2016-0000 (accessed 23 January 2017).

von Brocke, K., and E. Perez (2009). 'Group Financing: From Thin Capitalization to Interest Deduction Limitation Rules'. International Transfer Pricing Journal, January/February: 29-35.

Wamser, G. (2014). 'The Impact of Thin-Capitalization Rules on External Debt Usage: A Propensity Score Matching Approach'. Oxford Bulletin of Economics and Statistics, 76(5): 764-81.

Webber, S. (2010a). 'Thin Capitalization and Interest Deduction Regulations'. Copenhagen Research Group on International Tax: Discussion Papers. Available at: coritacademic.org/wp-content/uploads/2011/12/CORIT-8-Thin-Capitalization-and-EarningsStripping-Regulations-2-1.pdf (accessed 10 September 2016).

Webber, S. (2010b). 'Thin Capitalization and Interest Deduction Rules: A Worldwide Survey'. Tax Notes International, 60(9): 683-708.

Yao, J. (2013). 'The Arm's Length Principle, Transfer Pricing and Location Choice'. Journal of Economics and Business, 65: 13. 